\title{
Immune dysfunction in spaceflight and diabetes mellitus - translating space observations to terrestrial disease
}

Adil S. Ahmed, MD1,2, Vignesh Ramachandran, BS11, Daniel K. O'Conor, BS ${ }^{1}$, Erik L. Antonsen, MD, Ph.D. ${ }^{1,3,4}$ MJM 2019 17(13)

\section{Abstract}

Introduction: Spaceflight alters normal physiology of cells and tissues seen on Earth. Immune cells and signaling molecules appear to be particularly affected, resulting in changes in leukocyte populations, such as signaling molecule responses to immune challenge, and effector function. Akin to spaceflight, diabetes mellitus produces significant immune system dysfunction. Applying observations and interventions from spaceflight to conditions such as diabetes mellitus may help to identify new approaches that combat their high clinical and financial burden.

Discussion: A literature review was conducted using PubMed, MEDLINE, and Google Scholar. Studies on immune cell function conducted in space and on diabetes mellitus-related immune dysfunction were included. Broad themes of immunosuppression were seen in both spaceflight and diabetes mellitus. Effects on lymphocytes, neutrophils, eosinophils, monocytes, fibroblasts, growth factors, and inflammatory factors are presented.

Conclusions: Immune responses to spaceflight and DM are inconsistent. The innate immune system responds similarly to spaceflight and DM. In contrast, the adaptive immune system responds differently to spaceflight than to DM. This difference may be the result of a glucocorticoid dominant response linked to innate immune suppression and an adaptive Th2 lymphocyte shift.

Relevance: Diabetes mellitus causes major morbidity and mortality. Further research is needed to elucidate mechanisms behind these differences and develop countermeasures for immunosuppression in space with application towards diabetic therapy on earth. Furthermore, commercial spaceflight makes it all the more necessary to elucidate these mechanisms as civilian participants with diabetes mellitus or other immune-altering conditions may soon be able to travel into space.

Tags: Cellular; diabetes mellitus; humoral; immune dysfunction; immune system; innate; microgravity; spaceflight

${ }^{1}$ Center for Space Medicine, Baylor College of Medicine, Houston, Texas, USA.

${ }^{2}$ Department of Orthopedic Surgery, University of South Florida Morsani College of Medicine, Tampa, Florida, USA.

${ }^{3}$ Johnson Space Center, National Aeronautics and Space Administration, Houston, Texas, USA.

${ }^{4}$ Department of Emergency Medicine, Baylor College of Medicine, Houston, Texas, USA.

Corresponding Author: Adil S. Ahmed, email adilahmed0000@gmail.com. 


\section{Introduction}

The prevalence of diabetes mellitus (DM) is projected to increase by $165 \%$ in the US by 2050 with tremendous economic costs (1). Besides hyperglycemia, complications of Diabetes Mellitus include hypertension, dyslipidemia, stroke, and cardiovascular disease (2). Prolonged hyperglycemia causes immune system dysfunction from reduced cellmediated and humoral immune capacity alongside diminished leukocyte function (3).

These immune system alterations are similar to those generated by short-duration (e.g. missions of less than 1 week aboard the International Space Station) and extended-duration spaceflight. Systemically, spaceflight-induced immunosuppression causes decreased lymphoid cell reactivity, virus reactivation, increased infection rates, and impaired wound healing (4-6). On a cellular level, decreased immune cell function, gene expression, signal transduction pathways, and cytokine secretion are observed. The combined effects of microgravity, radiation exposure, and stress have been implicated as causing these effects (5).

Since space exploration began in 1961, voyages have increased in duration, subjecting astronauts to more sustained physiological changes. The massive cost of launching resources and personnel (estimated at $\$ 10,000$ per pound) has inherently limited the number of human spaceflight subjects and space infrastructure available to conduct direct human research in space (7). Therefore, terrestrial analogs, (ex. Antarctica isolation missions, head down tilt, and clinostat models) are used to study spaceflight-induced physiological phenomena (8). Recent research on immune system dysfunction has shifted to terrestrial conditions manifesting in space, such as rashes/hypersensitivities and latent viral reactivations $(5,6)$. However, a study assessing specific immune system derangements in space and comparing them to a disease with well-characterized immunoregulatory changes like DM is warranted to better understand the effects of spaceflight on the human being.

In this review, the effects of both spaceflight and DM on specific immune cells and signaling molecules are compared. While examining the unique conditions of spaceflight as a theoretical model for understanding immune dysfunction, we consider the putative crossover application to the study of immune alterations for DM populations.

\section{Methods}

This review was conducted using PubMed, MEDLINE, and Google Scholar for studies on immune function in spaceflight and DM. Search terms used for spaceflight studies include: 'spaceflight' / 'microgravity' / 'weightlessness' and 'wound' / 'immune' / 'complement' / 'cytokine' / 'advanced glycation end product' / 'neutrophil' / 'monocyte' / 'Iymphocyte' / 'eosinophil' / 'fibroblast' / 'macrophage' / 'platelet' / 'inflammation'. Additional terms resulted in duplicates.

Only studies of immune function carried out during spaceflight were included. 284 papers were surveyed. Papers not addressing the effects of spaceflight on the immune system and vasculature were excluded. Studies in simulated microgravity rather than real microgravity were also excluded. 37 papers were included for review.

Search terms used for DM studies were: 'diabetes' and 'wound' / 'immune' / 'complement' / 'cytokine' / 'advanced glycation end product' / 'neutrophil' / 'monocyte' / 'lymphocyte' / 'eosinophil' / 'fibroblast' / 'macrophage' / 'platelet' / 'inflammation' / 'diabetic ketoacidosis'. Additional terms resulted in duplicates. 310 papers were surveyed. Only papers describing the effects of diabetes, hyperglycemia, and diabetic emergencies on the immune system and vasculature were included. 43 papers were included for review.

\section{Results}

Overall results are categorized in Tables 1 and 2, separated into spaceflight and DM immune changes, respectively, with further results presented.

\section{Lymphocytes}

Lymphocytes consist of T lymphocytes, B lymphocytes, and natural killer (NK) cells. T and B lymphocytes are a part of the adaptive immune system while NK cells are part of the innate immune system (9).

International Space Station (ISS) experiments demonstrate increased human lymphocyte apoptosis caused by DNA fragmentation and elevated mRNA levels of apoptotic hallmarks like p53 and calpain $(10,11)$. Fitzgerald et al. posit that spaceflight hinders early lymphocyte activation by illustrating the effects of timing of polyclonal activation by pokeweed mitogen (PWM) on ex vivo lymphocyte immunoglobulin (lg) and cytokine production and metabolism (12). Pre-flight PWM exposure induces an 
increased metabolic rate in space-exposed lymphocytes up to control levels, whereas lymphocyte exposure to PWM during spaceflight does not.

Additionally, lymphocytes in spaceflight exposed to PWM do not increase Ig production whereas pre-flight activation with PWM increases Ig production (albeit slightly lower than pre-activated controls that have not experienced spaceflight). Lastly, lymphocytes activated with PWM during spaceflight do not increase cytokine production whereas pre-flight activation with PWM increases production to I levels seen in controls activated and cultured on the ground.

Lymphocyte alterations in DM are discussed in the following lymphocyte subsections.

\section{T Cells}

T lymphocytes are effectors of the cell-mediated immune response. CD4+ T-helper (Th) cells stimulate proliferation of plasma cells and CD8+ T cells. Regulatory $T$ cells modulate $T$ lymphocyte response. Upon stimulation, T lymphocytes undergo clonal selection forming memory cells for secondary exposure to antigens (13).

In spaceflight, there is decreased T cell activation and activity, decreased type IV hypersensitivity response, and a Th2 shift $(4,14,15)$. Human peripheral blood lymphocytes studied aboard SLS-1 and IML-2 (Shuttle Spacelab Missions) using a T cell activator (concanavalin A) indicate a 56\% depression of Interleukin-2 (IL-2) and IL-2 receptor secretion (14). This depression of the IL-2 receptor is thought to account for the decreased T cell activity observed in microgravity. (14)

Conversely, Crucian et al. found an increase in T cell function during short-term space missions (i.e., shuttle flights) and a decrease in T cell function in long-term missions (i.e., ISS missions) (16). Also observed was a Th2 cytokine shift towards humoral immunity over cell-mediated immunity, suggesting increased susceptibility to autoimmune disease, hypersensitivity reactions, and infectious processes (16). Another study of 15 astronauts revealed that 14 out of the 15 astronauts experienced a decreased delayed hypersensitivity response after exposure to a commercially-available hypersensitivity test (4).

Zhen et al. show that while there is an increase in the number of circulating T-regulatory cells in DM, their function is depressed (17). The hyperglycemic environment also affects a subset of T cells known as $\gamma \delta-T$ cells. $\gamma \delta-T$ cells normally reside in epithelium and function in barrier defense and post-injury wound healing (18). Another study using murine epithelial $\gamma \delta-$ $T$ cells showed chronically elevated tumor necrosis factor- $a(T N F-a)$ in hyperglycemia leads to $\gamma \delta-T$ cell dysfunction (18).

\section{B Cells}

Adaptive immunity is comprised of B lymphocytes, which form plasma cells producing Ig after stimulation by cytokines and interleukins. B cells, like T cells, are capable of forming memory cells providing accelerated response to secondary antigen exposure (19).

Studies on human B lymphocyte levels have indicated insignificant changes in space $(20,21)$. However, an experiment by Boxio et al. using adult ribbed newt indicates a shift in Ig plasma concentrations. After being flown five months aboard Mir space station, their spleens were analyzed ten days after landing. $\lg Y$, the homolog to human $\lg A$, was found to be elevated (22).

In DM, hyperglycemia lead to decreased release of IgM and ATP. When challenged with S. aureus, B cells exhibit a 55\% decrease in P2X7 receptor-dependent secretion of IgM compared to controls. This may result in under-stimulation and differentiation of $B$ cells in DM (23).

\section{Natural Killer Cells}

NK cells are lymphocyte-origin cells which exhibit innate immune system functions. NK cells target tumor cells, viruses, and some normal cells in the bone marrow and thymus (24).

NK cells in spaceflight show diminished counts and function. Fushs et al. demonstrated a reduction in NK cell cytotoxicity in humans and rats during both shortduration (defined as 3 months) and long-duration (up to 11 months) spaceflight, which was more prominent in the extended flight population (25). Similarly, a study of 72 astronauts showed reduced capacity of NK cells to recognize and kill target pathogens for up to 1-week post-flight after 3-11 months of spaceflight. Spaceflight-induced alterations in the ultrastructure of NK cell secretory and locomotor machinery are implicated (26). Furthermore, Tipton et al. and Crucian et al. report elevated neutrophil levels while NK cells are decreased in short-duration and long-duration crewmembers $(16,27)$. Alternatively, Mehta et al. report 10 astronauts with unchanged NK cell numbers during preflight, within three hours post-flight, and 
three days post-flight (28). However, cytotoxicity and lytic activity were decreased to approximately $40 \%$ of preflight values possibly due to stress response during spaceflight; post-flight urinary cortisol levels were also increased (28).

Type 2 diabetics have profound decreases in both NKG2D-positive NK cells and NKp46-positive cells compared to control subjects (29). Reduced expression of these receptors on NK cells is associated with impaired function (ex. reduced degranulation) when challenged with tumor cell lines (29). Furthermore, decreased NK cytotoxicity and lytic activity has been attributed to reduced expression of cell surface markers NKp30/p46 (30). These results are compatible with that of Lorini et al. who found lowered number and cytotoxic activity of CD16+ NK cells in type I diabetics compared with controls (31).

\section{Monocytes}

Monocytes of the innate immune system give rise to cells in tissues that can influence the adaptive immune system through antigen presentation, cytokine production, and receptor expression (32).

Mature monocytes include macrophages and dendritic cells that function in phagocytosis, migration, antigen presentation, and cytokine production.

A study of monocytes in 25 astronauts and nine healthy control subjects across four missions of 5-11day duration was performed by Kaur et al. Except for a surge immediately post-flight, monocyte counts three days post-flight and ten days pre-flight were comparable. Phagocytic ability was significantly reduced immediately post-flight and three days postflight. Oxidative burst and degranulation ability were constant pre- and post-flight; however, this was significantly lower than that of healthy controls. The authors also found decreased expression of CD32 and CD64, monocytic surface markers for complement activation. Overall, the results showed decreased phagocytic ability (33).

Monocytes of astronauts show upregulation of toll-like receptor 4, which recognizes lipopolysaccharide (LPS) in gram-negative bacteria (34). When challenged with LPS, astronauts' monocytes show decreased production of IL- 6 and IL1- $\beta$, increased expression of IL-8 (a granulocyte chemoattractant posited to contribute to granulocyte demargination upon landing), and increased expression of IL-1ra (IL-1 receptor antagonist). The astronauts' monocytes also expressed increased levels of LPS-binding protein.
These irregular values returned to normal levels after five months except for IL-1ra, which remained elevated five-fold compared to controls even at six to twelve months after landing. This illustrates diminished response of spaceflight-exposed monocytes to gram-negative bacterial challenge (34).

DM results in decreased monocytic chemotaxis, phagocytosis, and altered response to LPS(35). Geerlings et al. and Peleg et al. demonstrated monocytes isolated from patients with DM express lower levels of cytokines including IL-1 and IL-6 compared to normal patients $(35,36)$. Conversely, the prolonged inflammatory response to injury in DM patients leads to an increase in monocyte numbers and overproduction of inflammatory cytokines (37).

\section{Growth Factors}

Growth factors regulate cellular proliferation. Hematopoietic growth factors are important cells for the growth, survival and differentiation of blood cells and include colony stimulating factor (CSF) for the induction of lymphocyte hematopoiesis and transformative growth factor- $\beta$ (TGF- $\beta$ ) for the inflammation/fever response (38). An inhibitor of cell division, TGF- $\beta$ antagonizes growth factors that promote anabolism, such as fibroblast growth factor (FGF), platelet-derived growth factor (PDGF), insulinlike growth factor-1 (IGF-1), and vascular endothelial growth factor (VEGF) (39).

Davidson et al. studied the effects of spaceflight on the intrinsic capacity of rats to form granulation tissue in a simulated wound after injection of FGF and PDGF (40). Results showed blunted response of granulation tissue formation to PDGF and FGF in flight animals compared to ground controls, which exhibited increased granulation tissue production. The flight group showed decreased cellularity and decreased collagen concentration of granulation tissue (40).

Mirza et al. identified that macrophage TGF- $\beta$ and IGF-1 production is decreased in wound sites in diabetic mice (41). Lerman et al. report that VEGF, another essential protein in wound healing, is underproduced in diabetic murine fibroblasts (42).

\section{Neutrophils}

Neutrophils undergo granulopoiesis in the bone marrow, and secrete defensins, myeloperoxidase, and lysozyme to disrupt bacterial cell walls as part of oxidative burst (43). 
Short-duration spaceflights (2-11 days) result in increased leukocytes predominantly due to elevations in neutrophils (27). Similarly, study of blood hematopoietic cells in ribbed newts in spaceflight revealed an increase in the relative proportion of new neutrophils (44).

Stowe et al. investigated the effects of 8-15 days of spaceflight on circulating subpopulations of leukocytes, stress-induced hormones, Ig levels, and neutrophil function (45). Results indicated a 1.5-fold increase in neutrophils and a statistically significant slight decrease $(<10 \%)$ in lymphocytes upon landing compared to pre-flight measurements (45). Urinary epinephrine, norepinephrine, and cortisol were significantly increased after landing. The increase in band neutrophils (9/16 astronauts) was implicated by with the increase in cortisol. Similarly, elevated epinephrine was posited to contribute to the increase in plasma neutrophils and reduced marginated pool, which refers to the neutrophils adhered to blood vessel walls. Neutrophils are known to demarginate in response to stress hormones such as cortisol and epinephrine. Neutrophils exhibited different adhesion molecule expression, with increased L-selectin and decreased MAC-1 from spaceflight (45).

Kaur et al. analyzed neutrophil phagocytosis, oxidative burst, and degranulation ability in twenty five astronauts during four shuttle missions (5-11 days) compared to nine control subjects (46). Results illustrated neutrophils were increased in number by $85 \%$ at landing compared to preflight values.

Escherichia coli phagocytosis and oxidative burst abilities were not significantly altered in astronauts landing after five-day missions. However, these two metrics were significantly lower than those in controls for the 9- to 11-day missions. Surface marker expression and degranulation changes were not observed before or after missions (46).

Neutrophils exhibit decreased adherence, chemotaxis, phagocytosis, and oxidative burst capability in type 1 and type 2 DM(47). Furthermore, L-selectin, a marker of neutrophil activation, is increasingly shed and results in increased adhesion to the endothelium (48).

\section{Eosinophils}

Eosinophils kill helminths, modulate inflammation, and account for $2 \%$ of leukocytes (49).
Aboard biosatellite Cosmos-2229, ribbed newts were investigated for changes in blood hematopoietic cells. After a twelve day spaceflight, the animals showed a several-fold decrease in the number of lymphocytes and eosinophils (44).

Diabetic ketoacidosis (DKA) is an emergency of DM. In DKA, eosinophil counts are greatly reduced compared to non-DKA diabetic patients and non-DM controls. Non-DKA diabetics and normal controls have median normal eosinophil counts of 6595/mm3 and 6008/mm3, respectively, while DKA diabetics median eosinophil count is $28 / \mathrm{mm} 3(50)$.

\section{Fibroblasts}

Fibroblasts produce extracellular matrix and collagen, providing the structural framework for animal tissues playing a key role in wound healing (51).

Experiments aboard Cosmos-2229 by Tairbekov et al. demonstrated morphologic changes in nucleus size and shape of fibroblasts as well as delayed cell growth and division rate compared to control conditions (52). From 1995-1997, a series of studies of individual fibroblasts and cell associations were performed under various gravity conditions (0.00001$5 \mathrm{~g}$ ) using clinostats, centrifuges, and real microgravity in space. The results showed cultured fibroblasts in space exhibit decreased growth rate, inhibited cell division, and inhibited migration compared to controls (53). In another study, human fibroblasts underwent gene expression changes after spaceflight, relegating them to premature replicative senescence or apoptosis (54). Further experiments show a decrease in fibroblast progenitor cells in the bone marrow of rats after 14 days of spaceflight on the Cosmos-2044 biosatellite (55). Moreover, fibroblasts in space produced $146 \%$ increased collagen in vitro relative to controls (56).

Fibroblasts undergo similar modifications in DM. Brem et al. cultured fibroblasts from diabetic foot ulcers showing reduced migration and proliferation capability in relation to controls(57). Loots et al. similarly cultured fibroblasts from diabetic ulcers and found irregular intracellular morphologies such as dilated endoplasmic reticulum and lack of microtubular structures. Additionally, fibroblasts showed decreased proliferative capability compared to controls from non-diabetics (58).

Diabetic mouse fibroblasts in vitro demonstrated abnormal response to hypoxic challenge compared with controls. DM fibroblasts were not stimulated and 
did not increase VEGF production unlike controls (increased VEGF three-fold) (42). Additional studies in diabetic rats showed $50 \%$ decrease in collagen production, but without decrease in other proteins (59).

\section{Inflammatory Markers}

$\mathrm{IL}-1$ is a major proinflammatory cytokine that potentiates immunocompetent cells(60). In humans, IL-10 is produced in greatest quantities by regulatory $T$ cells and is anti-inflammatory. IL-15 mediates $\mathrm{T}$ cell proliferation (61). TNF-a is a pro-inflammatory cytokine (62). IFN- $\gamma$ activates monocytes, which increases inflammatory signaling contributing to chronic inflammation (63).

Cell and molecular-based studies in spaceflight by Semov et al. identified changes in TNF-a and ILrelated gene expression in space-flown human fibroblasts. TNF-a converting enzyme (TACE), a molecule that cleaves TNF-a into functional form, is induced in fibroblasts during spaceflight (64). This leads to elevated TNF-a levels without any change in TNF-a mRNA levels. Additionally, Semov et al. found downregulation of IL-15 receptor a chain (IL-15ra). The ligand of IL-15ra is IL-15, which is a regulator of macrophage pro-inflammatory cytokines. There is also upregulation of IL-1rn, a receptor antagonist of IL-1 $\alpha$ and IL-1 $\beta$ which neutralizes their function. The authors hypothesize that the changes in IL-15ra and $\mathrm{IL}-1 \mathrm{rn}$ are attempts to regulate pro-inflammatory states and bone resorption (64).

Crucian et al. show that in short and longer-duration spaceflight there is a decrease in IFN- $\gamma$ :IL10 ratio, favoring a switch to the Th2 subset of CD4+ T cells(16). Alternatively, Irina et al. found that IFN- $\gamma$ exhibited both increased and decreased levels in different astronauts during 3-11 month spaceflight (26).

Inflammatory factors are elevated in DM patients. CD4+CD28null T-lymphocytes, which are not found at high levels in non-diabetic patients, are increased in DM. This T-cell population secretes high levels of inflammatory cytokines, including IFN- $\gamma$ (65). Multiple studies have shown that in diabetic wounds, a proinflammatory state is promoted via increased levels of $\mathrm{IL}-1 \beta$ and TNF- $\alpha$ along with decreased levels of IL-10, TGF- $\beta$, and IGF-1 $(37,41)$. Additionally, Taylor et al. found TNF-a to be chronically elevated in hyperglycemic mice (18).

\section{Discussion}

The literature surveyed illustrates broad themes of immunosuppression and effector cell dysfunction in both spaceflight and DM. It is important to note that the body of research in DM is significantly larger than that in spaceflight. Thus, the diabetes literature offers specific insights that may not yet be elucidated in spaceflight research.

With few exceptions, spaceflight and DM exert similar effects on the innate component of the immune system (i.e. neutrophils, eosinophils, NK cells, monocytes, adhesion molecules, and fibroblasts) and different effects on the adaptive component (i.e. B cells and T cells). For instance, neutrophils increase Lselectin expression and decrease killing ability in both spaceflight and DM. Conversely, spaceflight does not seem to impact B cell function while DM depresses B cell function. Effects on other cells and molecules studied, such as endothelium and immunoglobulins, are still unclear.

Glucocorticoids such as cortisol have been shown to suppress inflammation, a process initiated by the innate immune system (66). During spaceflight, cortisol levels appear to be elevated. Studies demonstrated that, compared to pre-flight values, cortisol levels were significantly elevated during day 1 of Space Launch System-1 (SLS-1), the majority of the 15-day SLS-2 mission, and days 1-4 of Space Transportation System-95 (67-69). Cortisol levels measured during missions longer than 80 days, such as Skylab, Salyut and Mir, were mostly elevated compared to pre-flight values with a few exceptions (70-72). The variability in cortisol levels in longer term missions may be due to mission specific stressors (73). Nevertheless, the marked increase in glucocorticoids in astronauts during spaceflight may significantly suppress innate immunity.

The difference in effects of DM and spaceflight on the adaptive immune system may be explained by the Th2 shift observed in astronauts (16). A similar lymphocyte shift towards the Th2 subset has been described during stress responses (74), and may counteract any decrease in humoral immunity that would otherwise be observed in spaceflight (74). This may explain the unchanged humoral immune function in astronauts. Type I DM patients have been shown to have Th1 dominant cytokines and a deficiency in Th2 activity (74). The absence of observed Th2 shift in DM may account for differing adaptive immune response between the conditions. 
One particularly striking difference between DM and spaceflight is the response of fibroblasts. Fibroblasts increase collagen synthesis in space and decrease collagen synthesis in DM $(56,75)$. The increased fibroblast activity in spaceflight is an exception to the observed pattern of innate immune suppression. It is important to note, however, that the increased fibroblastic activity in space was observed in vitro while the decreased fibroblastic activity in diabetic mice was observed in vivo $(56,75)$. Specific in vivo experiments on human fibroblast collagen synthesis in space were not found. The increase in collagen synthesis in vitro may be a fibroblastic response to mechanical unloading resulting from microgravity.

The present study has several limitations, primarily due to the nature of spaceflight experiments. In the spaceflight literature, there exists variability in organismal model, mission duration, and various confounding factors. For instance, studies utilizing ribbed newts indicate a shift towards increased immunoglobulin secretion whereas human studies have shown constant levels of immunoglobulin $(20,22)$. Launch and landing times as well as postmission dissection time for animal models also affect study results. Other confounding factors include concurrent effects of microgravity, radiation, psychological stress, and altered circadian rhythms on astronauts. Additionally, the variation between populations in DM studies (eg. Type I vs Type II DM, adult vs. pediatric, level of glycemic control) limits our ability to more precisely define effects of DM on the immune system.

\section{Conclusion}

Ultimately, spaceflight and diabetes mellitus both result in immune dysfunction, with notably similar deleterious effects on the innate arm of the immune system. Given the ubiquitous and damaging nature of DM on patients and health systems worldwide, continued research and development of novel diagnostic and therapeutic modalities is imperative. Due to the similarity of innate immune effects presented between DM and spaceflight, the unique conditions of spaceflight may serve as a theoretical model for understanding immune dysfunction with crossover application to such study in DM. Such interdisciplinary research may lend itself to basic science discoveries and advances in prevention and therapeutics in both domains. As spaceflight scientific research in general is still a nascent field, it is reasonable to follow continued work in this area to help inform a more complete picture of the immune effects for comparison with terrestrial diseases.
Further comparative investigation focusing on specific elements of cellular and molecular dysfunction may identify possible countermeasure development with beneficial applications both for spaceflight and crossover application against diabetic immunosuppression across the globe. Further, the unique environment of spaceflight provides a valuable platform to observe and apply interventions for altered physiology that will likely yield interventions for other terrestrial health issues. Future space exploration will only lead to longer missions and the elucidation of new physiologic alterations; application of such findings in a space-to-ground pathway can yield translational clinical benefit to multiple disease states, such as visual impairment, autoimmunity, hypersensitivity, viral infection, and latent reactivation.

\section{Supplementary Content}

Table 1: Summary of the effects of spaceflight on the immune system.

Table 2: Summary of the effects of diabetes mellitus on the immune system.

\section{References}

1. Boyle JP, Honeycutt AA, Narayan KMV, Hoerger TJ, Geiss LS, Chen H, et al. Projection of diabetes burden through 2050: Impact of changing demography and disease prevalence in the U.S. Diabetes Care. 2001;24(11):1936-40.

2. Chawla A, Chawla R, Jaggi S. Microvasular and macrovascular complications in diabetes mellitus: Distinct or continuum? Indian J Endocrinol Metab. 2016;20(4):546.

3. Ahmed AS, Antonsen EL. Immune and vascular dysfunction in diabetic wound healing. J Wound Care. 2016;25(Sup7):S35-46.

4. Cogoli A. The effect of space flight on human cellular immunity. Environ Med. 1993;37:107-16.

5. Crucian B, Babiak-Vazquez A, Johnston S, Pierson DL, Ott CM, Sams C. Incidence of clinical symptoms during long-duration orbital spaceflight. Int $\mathrm{J}$ Gen Med. 2016;9:383-91.

6. Mehta SK, Laudenslager ML, Stowe RP, Crucian BE, Sams CF, Pierson DL. Multiple latent viruses reactivate in astronauts during Space Shuttle missions. Brain Behav Immun. 2014;41(1):210-7.

7. NASA Marshall Spaceflight Center. Advanced Space Transportation Program: Paving the Highway to Space [Internet]. 2008 [cited 2019 Aug 25]. Available from: https://www.nasa.gov/centers/marshall/news/backgro und/facts/astp.html

8. Ploutz-Snyder L. Evaluating countermeasures in spaceflight analogs. J Appl Physiol. 2015 Dec;120(8):915-21.

9. Alam R, Gorska M. Lymphocytes. J Allergy Clin Immunol. 2003;111(2 Suppl):S476-85. 
10. Battista N, Meloni MA, Bari M, Mastrangelo N, Galleri G, Rapino C, et al. 5-Lipoxygenase-dependent apoptosis of human lymphocytes in the International Space Station: data from the ROALD experiment. FASEB J. 2012;26(5):1791-8.

11. Maccarrone M, Bari M, Finazzi-Agro A, Meloni MA, Ranalli M, Pippia P, et al. Role of Apoptosis in Lymphocyte Depression (ROALD) - 11.22.16.

12. Fitzgerald W, Chen S, Walz C, Zimmerberg J, Margolis L, Grivel JC. Immune suppression of human lymphoid tissues and cells in rotating suspension culture and onboard the International Space Station. Vitr Cell Dev Biol Anim. 2009;45(10):622-32.

13. Starr TK, Jameson SC, Hogquist KA. Positive and negative selection of $\mathrm{T}$ cells. Annu Rev Immunol. 2003;21(1):139-76.

14. Cogoli A. Gravitational physiology of human immune cells: a review of in vivo, ex vivo and in vitro studies. J Gravit Physiol. 1996;3(1):1-9.

15. Crucian B, Sams C. Immune system dysregulation during spaceflight: clinical risk for exploration-class missions. J Leukoc Biol. 2009;86(5):1017-8.

16. Crucian BE, Stowe RP, Pierson DL, Sams CF. Immune system dysregulation following short- vs long-duration spaceflight. Aviat Sp Environ Med. 2008;79(9):835-43.

17. Zhen Y, Sun L, Liu H, Duan K, Zeng C, Zhang L, et al. Alterations of peripheral CD4+CD25+Foxp3+ $\mathrm{T}$ regulatory cells in mice with STZ-induced diabetes. Vol. 9, Cellular and Molecular Immunology. 2012. p. 75-85.

18. Taylor KR, Mills RE, Costanzo AE, Jameson JM. ???? $\mathrm{T}$ cells are reduced and rendered unresponsive by hyperglycemia and chronic TNF?? in mouse models of obesity and metabolic disease. PLoS One. 2010;5(7).

19. Pieper K, Grimbacher B, Eibel H. B-cell biology and development. Vol. 131, Journal of Allergy and Clinical Immunology. 2013. p. 959-71.

20. Fuchs BB, Medvedev AE. Countermeasures for ameliorating in-flight immune dysfunction. J Leukoc Biol. 1993;54(3):245-52.

21. Rykova MP. Immune system of Russian cosmonauts after orbital space flights. Hum Physiol. 2013;39(5):557-66.

22. Boxio R, Dournon C, Frippiat J-P. Effects of a long-term spaceflight on immunoglobulin heavy chains of the urodele amphibian Pleurodeles waltl. J Appl Physiol. 2005;98(3):905-10.

23. Sakowicz-Burkiewicz M, Kocbuch K, Grden M, Maciejewska I, Szutowicz A, Pawelczyk T. High glucose concentration impairs ATP outflow and immunoglobulin production by human peripheral $B$ lymphocytes: Involvement of P2X7 receptor. Immunobiology. 2013;218(4):591-601.

24. Herberman RB. Natural killer cells. Annu Rev Med. 1986;37:347-52.

25. Fuchs BB, Medvedev AE. Countermeasures for ameliorating in-flight immune dysfunction. J Leukoc Biol. 1993;54:245-52.

26. Irina V, Konstantinova MD. Immune resistance of man in space flights. Acta Astronaut. 1991;23(C):123-7.

27. Tipton CM, Greenleaf JE, Jackson CG. Neuroendocrine and immune system responses with spaceflights. Med Sci Sports Exerc. 1996;28:988-98.
28. Mehta SK, Kaur I, Grimm EA, Smid C, Feeback DL, Pierson DL, et al. Decreased non-MHC-restricted (CD56+) killer cell cytotoxicity after spaceflight. J Appl Physiol. 2001;91(4):1814-8.

29. Berrou J, Fougeray S, Venot M, Chardiny V, Gautier JF, Dulphy $\mathrm{N}$, et al. Natural Killer Cell Function, an Important Target for Infection and Tumor Protection, Is Impaired in Type 2 Diabetes. PLoS One. 2013;8(4).

30. Rodacki M, Svoren B, Butty V, Besse W, Laffel L, Benoist $C$, et al. Altered natural killer cells in type 1 diabetic patients. Diabetes. 2007;56(1):177-85.

31. Lorini R, Moretta A, Valtorta A, d'Annunzio G, Cortona L, Vitali L, Bozzola M SF. Cytotoxic activity in children with insulin-dependent diabetes mellitus. Diabetes Res Clin Pr. 1994;23(1):37-42.

32. Randolph GJ, Jakubzick C, Qu C. Antigen presentation by monocytes and monocyte-derived cells. Vol. 20, Current Opinion in Immunology. 2008. p. 52-60.

33. Kaur I, Simons ER, Castro V a., Ott CM, Pierson DL. Changes in monocyte functions of astronauts. Brain Behav Immun. 2005;19:547-54.

34. Kaur I, Simons ER, Kapadia AS, Ott CM, Pierson DL. Effect of spaceflight on ability of monocytes to respond to endotoxins of gram-negative bacteria. Clin Vaccine Immunol. 2008;15(10):1523-8.

35. Geerlings SE, Hoepelman Al. Immune dysfunction in patients with diabetes mellitus (DM). FEMS Immunol Med Microbiol. 1999;26:259-65.

36. Peleg AY, Weerarathna T, McCarthy JS, Davis TME. Common infections in diabetes: Pathogenesis, management and relationship to glycaemic control. Vol. 23, Diabetes/Metabolism Research and Reviews. 2007. p. 3-13.

37. Wetzler C, Kampfer H, Stallmeyer B, Pfeilschifter J, Frank S. Large and sustained induction of chemokines during impaired wound healing in the genetically diabetic mouse: Prolonged persistence of neutrophils and macrophages during the late phase of repair. $J$ Invest Dermatol. 2000;115:245-53.

38. Ornitz DM, Itoh N. Fibroblast growth factors. Genome Biol. 2001;2(3):REVIEWS3005.

39. Elliott RL, Blobe GC. Role of transforming growth factor beta in human cancer. J Clin Oncol. 2005;23(9):207893.

40. Davidson JM, Aquino AM, Woodward SC, Wilfinger WW. Sustained microgravity reduces intrinsic wound healing and growth factor responses in the rat. FASEB J. 1999;13:325-9.

41. Mirza RE, Fang MM, Ennis WJ, Kohl TJ. Blocking interleukin-1?? induces a healing-associated wound macrophage phenotype and improves healing in type 2 diabetes. Diabetes. 2013;62:2579-87.

42. Lerman OZ, Galiano RD, Armour M, Levine JP, Gurtner GC. Cellular Dysfunction in the Diabetic Fibroblast: Impairment in Migration, Vascular Endothelial Growth Factor Production, and Response to Hypoxia. Am J Pathol. 2003;162(1):303-12.

43. Nathan C. Neutrophils and immunity: challenges and opportunities. Nat Rev Immunol. 2006;6(3):173-82.

44. Michurina T V, Domaratskaya El, Nikonova TM, Khrushchov NG. Blood and clonogenic hemopoietic cells of newts after the space flight. Adv Space Res. 1996;17:295-8. 
45. Stowe RP, Sams CF, Mehta SK, Kaur I, Jones ML, Feeback DL, et al. Leukocyte subsets and neutrophil function after short-term spaceflight. J Leukoc Biol. 1999;65(February):179-86.

46. Kaur I, Simons ER, Castro VA, Mark Ott C, Pierson DL. Changes in neutrophil functions in astronauts. Brain Behav Immun. 2004;18:443-50.

47. Geerlings SE, Hoepelman a I. Immune dysfunction in patients with diabetes mellitus (DM). FEMS Immunol Med Microbiol. 1999;26(3-4):259-65.

48. Karadayi K, Top C, Gulecek O. The relationship between soluble L-selectin and the development of diabetic retinopathy. Ocul Immunol Inflamm. 2003;11(2):123-9.

49. Kita H. Eosinophils: Multifaceted biological properties and roles in health and disease. Immunol Rev. 2011;242(1):161-77.

50. Xu W, Wu HF, Ma SG, Bai F, Hu W, Jin Y, et al. Correlation between peripheral white blood cell counts and hyperglycemic emergencies. Int $\mathrm{J}$ Med Sci. 2013;10(6):758-65.

51. Sorrell JM, Caplan Al. Fibroblast heterogeneity: more than skin deep. J Cell Sci. 2004;117(Pt 5):667-75.

52. Tairbekov MG, Margolis LB, Baibakov BA, Gabova A V, Dergacheva G V. Growth And Motility Of Cell-Culture In Microgravity Conditions (Experiment Fibroblast). Izv Akad Nauk Seriya Biol. 1994;745-50.

53. Tairbekov MG. The cell as a gravity-dependent biomechanic system. Aviakosm Ekolog Med. 2000;34:3-17.

54. Liu Y, Wang E. Transcriptional Analysis of Normal Human Fibroblast Responses to Microgravity Stress. Genomics Proteomics Bioinformatics. 2008;6(1):29-41.

55. Vacek A, Michurina T V., Serova L V., Rotkovska D, Bartonickova A. Decrease in the number of progenitors of erythrocytes (BFUe, CFUe), granulocytes and macrophages (GM-CFC) in bone marrow of rats after a 14-day flight onboard the Cosmos-2044 biosatellite. Folia Biol (Praha). 1991;37:35-41.

56. Seitzer U, Bodo M, Müller PK, Açil Y, Bätge B. Microgravity and hypergravity effects on collagen biosynthesis of human dermal fibroblasts. Cell Tissue Res. 1995;282(3):513-7.

57. Brem H, Tomic-Canic M. Cellular and molecular basis of wound healing in diabetes. $J$ Clin Invest. 2007;117:1219-22.

58. Loots MAM, Lamme EN, Mekkes JR, Bos JD, Middelkoop E. Cultured fibroblasts from chronic diabetic wounds on the lower extremity (non-insulindependent diabetes mellitus) show disturbed proliferation. Arch Dermatol Res. 1999;291:93-9.

59. Spanheimer RG, Umpierrez GE, Stumpf V. Decreased collagen production in diabetic rats. Diabetes. 1988;37:371-6.

60. Sims JE, Smith DE. The IL-1 family: regulators of immunity. Nat Rev Immunol. 2010;10(2):89-102.

61. Akdis M, Burgler S, Crameri R, Eiwegger T, Fujita $\mathrm{H}$, Gomez E, et al. Interleukins, from 1 to 37 , and interferon- $\gamma$ : Receptors, functions, and roles in diseases. Vol. 127, Journal of Allergy and Clinical Immunology. 2011. p. 701-21.
62. Clark IA. How TNF was recognized as a key mechanism of disease. Cytokine Growth Factor Rev. 2007;18(34):335-43.

63. Liuzzo G, Vallejo AN, Kopecky SL, Frye RL, Holmes DR, Goronzy JJ, et al. Molecular fingerprint of interferongamma signaling in unstable angina. Circulation. 2001;103:1509-14.

64. Semov A, Semova N, Lacelle C, Marcotte R, Petroulakis E, Proestou G, et al. Alterations in TNF- and IL-related gene expression in space-flown WI38 human fibroblasts. FASEB J. 2002;16:899-901.

65. Nakajima T, Schulte S, Warrington KJ, Kopecky SL, Frye RL, Goronzy JJ, et al. T-cell-mediated lysis of endothelial cells in acute coronary syndromes. Circulation. 2002;105:570-5.

66. Clark AR. Anti-inflammatory functions of glucocorticoid-induced genes. Mol Cell Endocrinol. 2007;275(1-2):79-97.

67. Leach CS. Fluid control mechanisms in weightlessness. Aviat Sp Environ Med. 1987;58(9 Pt 2).

68. Leach CS, Alfrey CP, Suki WN, Leonard JI, Rambaut PC, Inners LD, et al. Regulation of body fluid compartments during short-term spaceflight. J Appl Physiol. 1996;81(1):105-16.

69. Stowe RP, Pierson DL, Feeback DL, Barrett a D. Stress-induced reactivation of Epstein-Barr virus in astronauts. Neuroimmunomodulation. 2000;8(2):51-8.

70. NASA. Biomedical Results from SKYLAB. Biomedical. 1977;500.

71. Gazenko OG, Schulzhenko EB, Grigoriev Al, Atkov OY, Egorov AD. Review of basic medical results of the Salyut-7-Soyuz-T 8-month manned flight. Acta Astronaut. 1988;17(2):155-60.

72. Grigoriev Al, Bugrov SA, Bogomolov V V., Egorov AD, Polyakov V V., Tarasov IK, et al. Main medical results of extended flights on space station Mir in 1986-1990. Acta Astronaut. 1993;29(8):581-5.

73. Stein TP, Leskiw MJ, Schluter MD, Donaldson MR, Larina I. Protein kinetics during and after long-duration spaceflight on MIR. Am J Physiol. 1999;276(6 Pt 1):E1014-21.

74. Elenkov IJ. Glucocorticoids and the Th1/Th2 balance. In: Annals of the New York Academy of Sciences. 2004. p. 138-46.

75. Spanheimer RG, Umpierrez GE, Stumpf V. Decreased collagen production in diabetic rats. Diabetes. 1988;37(4):371-6. 
Table 1. Summary of the effects of spaceflight on the immune system

Ig = immunoglobulin; NK = natural killer; IFN = interferon; ISS = International Space Station; mRNA = messenger ribonucleic acid; IL1 rn = interleukin-1 receptor antagonist; HUVEC = human umbilical vein endothelial cell; SLS-1 = Space Launch System-1; IML-2 = International Microgravity Library-2

\begin{tabular}{|c|c|c|c|c|c|c|}
\hline $\begin{array}{l}\text { Ref \# } \\
\text { B Cell }\end{array}$ & Year & Study Type & Objective & $\begin{array}{l}\text { Population } \\
\text { Investigated }\end{array}$ & $\begin{array}{l}\text { Flight } \\
\text { Duration }\end{array}$ & Findings \\
\hline 20 & 1993 & Review article & $\begin{array}{l}\text { Review of countering immune } \\
\text { dysfunction in spaceflight }\end{array}$ & $\begin{array}{l}\text { Humans in } \\
\text { spaceflight }\end{array}$ & Not reported & $\begin{array}{l}\text { Brief, reversible postflight increase of IgA/lgG } \\
\text { concentration but otherwise resistance of the } \\
\text { humoral immune system to influence of spaceflight }\end{array}$ \\
\hline 21 & 2013 & $\begin{array}{l}\text { Cohort } \\
\text { observational } \\
\text { studies }\end{array}$ & $\begin{array}{l}\text { Review of the qualitative and quantitative } \\
\text { changes in the innate and adaptive } \\
\text { immune systems of humans in } \\
\text { spaceflight }\end{array}$ & $\begin{array}{l}\text { Humans following } \\
\text { spaceflight }\end{array}$ & 8 to 195 days & $\begin{array}{l}\text { Levels of IgA, IgM, IgG did not change significantly } \\
\text { in the post flight blood serum of cosmonauts in 8- } \\
\text { 11-day missions and 128-195-day missions. }\end{array}$ \\
\hline 21 & 2013 & $\begin{array}{l}\text { Cohort } \\
\text { observational } \\
\text { study }\end{array}$ & $\begin{array}{l}\text { Review of the qualitative and quantitative } \\
\text { changes in the innate and adaptive } \\
\text { immune systems of humans in } \\
\text { spaceflight }\end{array}$ & $\begin{array}{l}\text { Human peripheral } \\
\text { blood cells following } \\
\text { spaceflight }\end{array}$ & $\begin{array}{l}169 \text { to } 438 \\
\text { days }\end{array}$ & $\begin{array}{l}\text { IgA, IgM, IgG synthesis by B-cells from cosmonauts } \\
\text { was significantly suppressed following stimulation } \\
\text { by Staphylococcus aureus on the first day following } \\
\text { 169- and 438-day spaceflights }\end{array}$ \\
\hline 22 & 2005 & $\begin{array}{l}\text { Parallel group } \\
\text { experimental } \\
\text { study }\end{array}$ & $\begin{array}{l}\text { Adult animals immunized in-spaceflight } \\
\text { and spleens analyzed for presence of } \\
\text { immunoglobulin post-spaceflight and } \\
\text { compared to animals living on Earth }\end{array}$ & $\begin{array}{l}\text { Pleurodeles waltl } \\
\text { aboard Mir space } \\
\text { station }\end{array}$ & 5 months & $\begin{array}{l}\text { IgY immunoglobulins in spaceflight animals were } \\
\text { three-fold elevated over animals living on Earth }\end{array}$ \\
\hline 25 & 1991 & $\begin{array}{l}\text { Cohort } \\
\text { observational } \\
\text { study }\end{array}$ & $\begin{array}{l}\text { Examination of mononuclear cells before, } \\
\text { during, and after spaceflight }\end{array}$ & $\begin{array}{l}72 \text { cosmonauts in } \\
\text { spaceflight }\end{array}$ & $\begin{array}{l}3 \text { to } 11 \\
\text { months }\end{array}$ & $\begin{array}{l}\text { Reduced capacity of NK cells to recognize and kill } \\
\text { target pathogens for up to a week post-spaceflight. } \\
\text { Spaceflight-induced alterations in the ultrastructure } \\
\text { of the NK cell secretory and locomotor machinery } \\
\text { may explain this occurrence }\end{array}$ \\
\hline \multicolumn{7}{|r|}{ 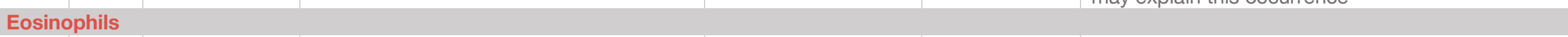 } \\
\hline 43 & 1996 & $\begin{array}{l}\text { Parallel group } \\
\text { experimental } \\
\text { study }\end{array}$ & Analysis of blood and hematopoetic cells & $\begin{array}{l}\text { Ribbed newts in } \\
\text { spaceflight }\end{array}$ & 12 days & Several-fold decrease in number of eosinophils \\
\hline \multicolumn{7}{|c|}{ Fibroblasts } \\
\hline 50 & 1994 & $\begin{array}{l}\text { Parallel group } \\
\text { experimental } \\
\text { study }\end{array}$ & $\begin{array}{l}\text { Comparison on time-related changes in } \\
\text { spaceflight-exposed cell morphology } \\
\text { compared to ground controls }\end{array}$ & $\begin{array}{l}\text { Mouse embryo } \\
\text { connective tissue } \\
\text { cells in spaceflight }\end{array}$ & & $\begin{array}{l}\text { Morphologic changes in nucleus size and delayed } \\
\text { cell growth and division rate compared to } 1 \mathrm{~g} \text { control } \\
\text { conditions }\end{array}$ \\
\hline 51 & 2000 & $\begin{array}{l}\text { Parallel group } \\
\text { experimental } \\
\text { study }\end{array}$ & $\begin{array}{l}\text { Comparison of cells cultured in space to } \\
\text { ground controls and simulated } \\
\text { microgravity }\end{array}$ & $\begin{array}{l}\text { Fibroblasts and } \\
\text { osteoblasts cultured } \\
\text { in spaceflight }\end{array}$ & & $\begin{array}{l}\text { Fibroblasts cultured on solid substrate in space } \\
\text { exhibit decreased growth rate, inhibited cell division, } \\
\text { and inhibited migration compared to ground controls }\end{array}$ \\
\hline 52 & 2008 & $\begin{array}{l}\text { Parallel group } \\
\text { experimental } \\
\text { study }\end{array}$ & $\begin{array}{l}\text { Evaluation gene expression in } \\
\text { comparison to ground controls }\end{array}$ & $\begin{array}{l}\text { Human fibroblasts in } \\
5 \text { days of spaceflight }\end{array}$ & 5 days & $\begin{array}{l}\text { Changes in gene expression following spaceflight } \\
\text { predispose fibroblasts to premature replicative } \\
\text { senescence or apoptosis }\end{array}$ \\
\hline 53 & 1991 & $\begin{array}{l}\text { Parallel group } \\
\text { experimental } \\
\text { study }\end{array}$ & $\begin{array}{l}\text { Bone marrow compared to ground } \\
\text { controls }\end{array}$ & $\begin{array}{l}\text { Rats exposed to } \\
\text { spaceflight }\end{array}$ & 14 days & $\begin{array}{l}\text { Decrease in number of fibroblast progenitor cells } \\
\text { was observed. }\end{array}$ \\
\hline 54 & 1995 & $\begin{array}{l}\text { Parallel group } \\
\text { experimental } \\
\text { study }\end{array}$ & $\begin{array}{l}\text { Analysis of collagen synthesis in } \\
\text { comparison to ground controls }\end{array}$ & $\begin{array}{l}\text { Human fibroblasts } \\
\text { grown in spaceflight } \\
\text { for } 4-20 \text { hours }\end{array}$ & $4-20$ hours & $\begin{array}{l}\text { Fibroblasts in spaceflight produced } 146 \% \text { increased } \\
\text { collagen in vitro relative to ground controls. }\end{array}$ \\
\hline
\end{tabular}




\begin{tabular}{|c|c|c|c|c|c|c|}
\hline $\begin{array}{l}\text { Ref \# } \\
\text { Growt }\end{array}$ & $\begin{array}{l}\text { Year } \\
\text { h Facto }\end{array}$ & $\begin{array}{l}\text { Study Type } \\
\text { rs }\end{array}$ & Objective & $\begin{array}{l}\text { Population } \\
\text { Investigated }\end{array}$ & $\begin{array}{l}\text { Flight } \\
\text { Duration }\end{array}$ & Findings \\
\hline 39 & 1999 & $\begin{array}{l}\text { Parallel group } \\
\text { experimental } \\
\text { study }\end{array}$ & $\begin{array}{l}\text { Analysis of wound healing in the } \\
\text { presence of growth factors }\end{array}$ & $\begin{array}{l}\text { Fisher-344 rats in } \\
\text { spaceflight }\end{array}$ & 10 days & $\begin{array}{l}\text { Blunted response of granulation tissue formation in } \\
\text { response to growth factors in spaceflight rats } \\
\text { compared to ground controls including decreased } \\
\text { cellularity and decreased collagen concentration }\end{array}$ \\
\hline \multicolumn{7}{|c|}{ Inflammatory Factors } \\
\hline 52 & 2008 & $\begin{array}{l}\text { Parallel group } \\
\text { experimental } \\
\text { study }\end{array}$ & $\begin{array}{l}\text { Post-spaceflight comprehensive immune } \\
\text { assessment including peripheral } \\
\text { leukocyte subset analysis, early T cell } \\
\text { activation potential, and } \\
\text { intracellular/secreted cytokine profiles }\end{array}$ & $\begin{array}{l}17 \text { Space Shuttle } \\
\text { crewmembers and } 8 \\
\text { ISS crewmembers }\end{array}$ & Not reported & $\begin{array}{l}\text { Increased IFN-gamma:IL10 ration decreased in } \\
\text { short- and long-duration spaceflight, favoring a } \\
\text { switch to the Th2 subset of CD4+ T cells. }\end{array}$ \\
\hline 25 & 1991 & $\begin{array}{l}\text { Cohort } \\
\text { observational } \\
\text { study }\end{array}$ & $\begin{array}{l}\text { Examination of mononuclear cells before, } \\
\text { during, and after spaceflight }\end{array}$ & $\begin{array}{l}72 \text { cosmonauts in } \\
\text { spaceflight }\end{array}$ & $\begin{array}{l}3 \text { to } 11 \\
\text { months }\end{array}$ & $\begin{array}{l}\text { IFN-gamma exhibited both increased and decreased } \\
\text { levels in different astronauts during spaceflight. }\end{array}$ \\
\hline 62 & 2002 & $\begin{array}{l}\text { Parallel group } \\
\text { experimental } \\
\text { study }\end{array}$ & Microarray analysis of mRNA expression & $\begin{array}{l}\text { Human fibroblasts } \\
\text { exposed to } \\
\text { spaceflight }\end{array}$ & Not reported & $\begin{array}{l}\text { TNF-alpha converting enzyme was induced in } \\
\text { fibroblasts during spaceflight, leading to increases in } \\
\text { TNF-alpha levels without increases in TNF-alpha } \\
\text { mRNA levels. Additionally, IL-15 receptor alpha } \\
\text { chain, whose ligand is a regulator of macrophage } \\
\text { pro-inflammatory cytokines, was found to be } \\
\text { downregulated. IL1rn was found to be upregulated. }\end{array}$ \\
\hline \multicolumn{7}{|c|}{ Lymphocytes } \\
\hline 12 & 2009 & $\begin{array}{l}\text { Parallel group } \\
\text { experimental } \\
\text { study }\end{array}$ & $\begin{array}{l}\text { In-flight and pre-flight polyclonal } \\
\text { activation of cells by pokeweed mitogen }\end{array}$ & $\begin{array}{l}\text { Human lymphoid } \\
\text { cells in spaceflight } \\
\text { aboard ISS }\end{array}$ & 12 days & $\begin{array}{l}\text { Spaceflight hinders early lymphocyte activation } \\
\text { events as evidenced by the absence of increased } \\
\text { metabolic and lg production rates and failure to } \\
\text { increase cytokine production upon exposure to } \\
\text { mitogens }\end{array}$ \\
\hline 44 & 1999 & $\begin{array}{l}\text { Cohort } \\
\text { observational } \\
\text { study }\end{array}$ & $\begin{array}{l}\text { Analysis of peripheral blood and } \\
\text { neutrophil-endothelial cell adhesion } \\
\text { assays }\end{array}$ & $\begin{array}{l}16 \text { astronauts in } \\
\text { spaceflight }\end{array}$ & $8-15$ days & $\begin{array}{l}\text { Slight decrease in lymphocyte count post- } \\
\text { spaceflight }\end{array}$ \\
\hline 10,11 & $\begin{array}{l}2012 \\
2016\end{array}$ & $\begin{array}{l}\text { Parallel group } \\
\text { experimental } \\
\text { study }\end{array}$ & $\begin{array}{l}\text { Cells activated aboard ISS compared to } \\
\text { cells activated on Earth }\end{array}$ & $\begin{array}{l}\text { Human peripheral } \\
\text { blood mononuclear } \\
\text { cells in spaceflight }\end{array}$ & $48 \mathrm{hrs}$ & $\begin{array}{l}\text { Spaceflight triggers human lymphocyte apoptosis as } \\
\text { evaluated by DNA fragmentation and accumulation } \\
\text { of p53 }\end{array}$ \\
\hline \multicolumn{7}{|c|}{ Monocytes } \\
\hline 32 & 2005 & $\begin{array}{l}\text { Parallel group } \\
\text { experimental } \\
\text { study }\end{array}$ & $\begin{array}{l}\text { Analysis of blood samples collected } 10 \\
\text { days pre-spaceflight and } 3 \text { hours and } 3 \\
\text { days post-spaceflight }\end{array}$ & $\begin{array}{l}25 \text { astronauts in } \\
\text { spaceflight }\end{array}$ & 5 to 11 days & $\begin{array}{l}\text { Except for a brief surge immediately post- } \\
\text { spaceflight, monocyte counts } 3 \text { days post- } \\
\text { spaceflight and } 10 \text { days pre-spaceflight were } \\
\text { comparable. Phagocytic ability was significantly } \\
\text { reduced and expression of monocytic surface } \\
\text { markers CD32 and CD } 64 \text { was decreased in } \\
\text { astronauts post-spaceflight }\end{array}$ \\
\hline
\end{tabular}




\begin{tabular}{|c|c|c|c|c|c|c|}
\hline Ref \# & Year & Study Type & Objective & $\begin{array}{l}\text { Population } \\
\text { Investigated }\end{array}$ & $\begin{array}{l}\text { Flight } \\
\text { Duration }\end{array}$ & Findings \\
\hline 33 & 2008 & $\begin{array}{l}\text { Parallel group } \\
\text { experimental } \\
\text { study }\end{array}$ & $\begin{array}{l}\text { Analysis of blood samples collected } 10 \\
\text { days pre-spaceflight and } 3 \text { hours, } 3 \text { days, } \\
\text { and } 15 \text { days post-spaceflight }\end{array}$ & $\begin{array}{l}20 \text { astronauts in } \\
\text { spaceflight }\end{array}$ & 10 to 13 days & $\begin{array}{l}\text { Post-spaceflight upregulation of toll-like receptor } 4 \\
\text { (TLR4) and downregulation of CD14. This was } \\
\text { accompanied by a diminished response of the } \\
\text { monocytes to gram-negative bacterial challenge as } \\
\text { measured by a decrease in production of IL-6 and } \\
\text { IL1-beta, and an increase of the IL-1 receptor } \\
\text { antagonist and IL-8 in comparison to controls. IL-8 } \\
\text { upregulation is posited as a contributing factor to } \\
\text { granulocyte demargination. }\end{array}$ \\
\hline \multicolumn{7}{|r|}{ 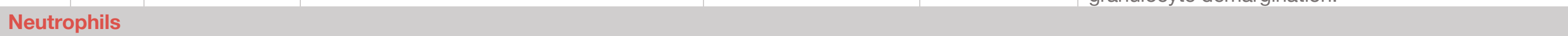 } \\
\hline 26 & 1996 & $\begin{array}{l}\text { Cohort } \\
\text { observational } \\
\text { studies }\end{array}$ & $\begin{array}{l}\text { Review of short- and long-term immune } \\
\text { suppression in humans in spaceflight }\end{array}$ & $\begin{array}{l}\text { Humans in } \\
\text { spaceflight }\end{array}$ & 2-57 days & Increase in neutrophils post-spaceflight \\
\hline 44 & 1999 & $\begin{array}{l}\text { Cohort } \\
\text { observational } \\
\text { study }\end{array}$ & $\begin{array}{l}\text { Analysis of peripheral blood and } \\
\text { neutrophil-endothelial cell adhesion } \\
\text { assays }\end{array}$ & $\begin{array}{l}16 \text { astronauts in } \\
\text { spaceflight }\end{array}$ & 8-15 days & $\begin{array}{l}\text { 1.5-fold increase in neutrophils post-spaceflight, } \\
\text { reduced marginated pool, and increased post- } \\
\text { spaceflight band cell counts in } 9 \text { of } 16 \text { astronauts } \\
\text { possibly related to elevated levels of urinary } \\
\text { epinephrine, norepinephrine, and cortisol }\end{array}$ \\
\hline 43 & 1996 & $\begin{array}{l}\text { Parallel group } \\
\text { experimental } \\
\text { study }\end{array}$ & Analysis of blood and hematopoetic cells & $\begin{array}{l}\text { Ribbed newts in } \\
\text { spaceflight }\end{array}$ & 12 days & Increase in the relative proportion of new neutrophils \\
\hline 45 & 2004 & $\begin{array}{l}\text { Parallel group } \\
\text { experimental } \\
\text { study }\end{array}$ & $\begin{array}{l}\text { Analysis of blood samples taken } 10 \text { days } \\
\text { pre-spaceflight, immediately upon } \\
\text { landing, and } 10 \text { days post-spaceflight } \\
\text { compared to } 9 \text { control subjects }\end{array}$ & $\begin{array}{l}25 \text { astronauts in } \\
\text { spaceflight }\end{array}$ & $5-11$ days & $\begin{array}{l}85 \% \text { increase in neutrophil counts immediately post- } \\
\text { spaceflight compared to } 10 \text { days pre-spaceflight. No } \\
\text { significant difference in Escherichia coli } \\
\text { phagocytosis or oxidative burst ability was observed } \\
\text { in astronauts landing from } 5 \text { days of spaceflight, but } \\
\text { these two metrics were significantly lower than } \\
\text { controls following 9-11 days of spaceflight. }\end{array}$ \\
\hline \multicolumn{7}{|c|}{ NK Cells } \\
\hline 27 & 2008 & $\begin{array}{l}\text { Parallel group } \\
\text { experimental } \\
\text { study }\end{array}$ & $\begin{array}{l}\text { Post-spaceflight comprehensive immune } \\
\text { assessment including peripheral } \\
\text { leukocyte subset analysis, early T cell } \\
\text { activation potential, and } \\
\text { intracellular/secreted cytokine profiles }\end{array}$ & $\begin{array}{l}17 \text { Space Shuttle } \\
\text { crewmembers and } 8 \\
\text { ISS crewmembers }\end{array}$ & Not reported & $\begin{array}{l}\text { Statistically significant decrease in NK counts post- } \\
\text { spaceflight }\end{array}$ \\
\hline 20 & 1993 & Review article & $\begin{array}{l}\text { Review of countering immune } \\
\text { dysfunction in spaceflight }\end{array}$ & $\begin{array}{l}\text { Humans in } \\
\text { spaceflight }\end{array}$ & Not reported & $\begin{array}{l}\text { Reduction in NK cell cytotoxicity in humans and } \\
\text { animals was observed during short-and long- } \\
\text { duration spaceflight, sometimes in concurrence with } \\
\text { a reduced production of interferons }\end{array}$ \\
\hline 26 & 1996 & $\begin{array}{l}\text { Cohort } \\
\text { observational } \\
\text { studies }\end{array}$ & $\begin{array}{l}\text { Review of short- and long-term immune } \\
\text { suppression in humans in spaceflight }\end{array}$ & $\begin{array}{l}\text { Humans in } \\
\text { spaceflight }\end{array}$ & 7-366 days & Decreased in NK cell count post-spaceflight \\
\hline 5 & 2001 & $\begin{array}{l}\text { Cohort } \\
\text { observational } \\
\text { study }\end{array}$ & $\begin{array}{l}\text { Analysis of blood samples collected } 10 \\
\text { days pre-spaceflight and } 3 \text { hours and } 3 \\
\text { days post-spaceflight }\end{array}$ & $\begin{array}{l}10 \text { astronauts in } \\
\text { spaceflight }\end{array}$ & 9 to 10 days & $\begin{array}{l}\text { No statistically significant change in NK cell counts } \\
\text { during or after spaceflight. Decrease in cytotoxicity } \\
\text { and lytic activity by approximately } 40 \% \text { post- } \\
\text { spaceflight possibly in association with increased } \\
\text { cortisol levels }\end{array}$ \\
\hline
\end{tabular}




\begin{tabular}{|c|c|c|c|c|c|c|}
\hline $\begin{array}{l}\text { Ref \# } \\
\text { Surfac }\end{array}$ & Year & $\begin{array}{l}\text { Study Type } \\
\text { sion Molecules }\end{array}$ & Objective & $\begin{array}{l}\text { Population } \\
\text { Investigated }\end{array}$ & $\begin{array}{l}\text { Flight } \\
\text { Duration }\end{array}$ & Findings \\
\hline 44 & 1999 & $\begin{array}{l}\text { Cohort } \\
\text { observational } \\
\text { study }\end{array}$ & $\begin{array}{l}\text { Analysis of peripheral blood and } \\
\text { neutrophil-endothelial cell adhesion } \\
\text { assays }\end{array}$ & $\begin{array}{l}16 \text { astronauts in } \\
\text { spaceflight }\end{array}$ & 8-15 days & $\begin{array}{l}\text { Increased L-selectin, decreased membrane attack } \\
\text { complexes, and increased adhesion of granulocytes } \\
\text { to TNF-alpha stimulated HUVEC }\end{array}$ \\
\hline \multicolumn{7}{|c|}{ T Cells } \\
\hline 4 & 1993 & $\begin{array}{l}\text { Cohort } \\
\text { observational } \\
\text { study }\end{array}$ & Human skin hypersensitivity test & $\begin{array}{l}15 \text { astronauts on US } \\
\text { space shuttle } \\
\text { missions and orbital } \\
\text { Mir station }\end{array}$ & 4 to 177 days & $\begin{array}{l}\text { Delayed skin hypersensitivity response in } \\
\text { astronauts, T-lymphocyte responsiveness to } \\
\text { mitogens depressed by average of } 56 \% \text { during and } \\
\text { after spaceflight }\end{array}$ \\
\hline 27 & 2008 & $\begin{array}{l}\text { Parallel group } \\
\text { experimental } \\
\text { study }\end{array}$ & $\begin{array}{l}\text { Post-spaceflight comprehensive immune } \\
\text { assessment including peripheral } \\
\text { leukocyte subset analysis, early T cell } \\
\text { activation potential, and } \\
\text { intracellular/secreted cytokine profiles }\end{array}$ & $\begin{array}{l}17 \text { Space Shuttle } \\
\text { crewmembers and } 8 \\
\text { ISS crewmembers }\end{array}$ & Not reported & $\begin{array}{l}\text { Increase in T-cell function during short term } \\
\text { spaceflight and decrease in T cell function during } \\
\text { long term missions. Th2 cytokine shift was } \\
\text { observed, indicating a shift towards humoral } \\
\text { immunity over cell-mediated immunity }\end{array}$ \\
\hline 14 & 1996 & $\begin{array}{l}\text { Cohort } \\
\text { observational } \\
\text { study }\end{array}$ & $\begin{array}{l}\text { T cell activation using concanavalin } A \\
\text { mitogen }\end{array}$ & $\begin{array}{l}\text { Human peripheral } \\
\text { blood lymphocytes } \\
\text { on SLS-1 and IML-2 } \\
\text { spaceflights }\end{array}$ & 2 to 366 days & $\begin{array}{l}\text { Spaceflight depresses IL-2 and IL-2 receptor } \\
\text { secretion in response to Con A mitogen }\end{array}$ \\
\hline
\end{tabular}


Table 2. Summary of the effects of diabetes mellitus on the immune system.

Ig = immunoglobulin; ATP = adenosine triphosphate; DKA = diabetic ketoacidosis; VEGF = vascular endothelial growth factor; IGF-1 = insulin-like growth factor-1, TGF = transforming growth factor; IL = interleukin; $\mathrm{mRNA}=$ messenger ribonucleic acid; ELISA = enzyme linked immunosorbent assay; LPS = lipopolysaccharide; NKG2D = Natural Killer Group 2D; NK = Natural Killer; STZ = Streptozotocin; Tregs = regulatory T cells

\begin{tabular}{|c|c|c|c|c|c|}
\hline $\begin{array}{l}\text { Ref \# } \\
\text { B Cel }\end{array}$ & \multicolumn{4}{|c|}{ B Cells } & Findings \\
\hline 23 & 2013 & $\begin{array}{l}\text { Parallel group } \\
\text { experimental } \\
\text { study }\end{array}$ & $\begin{array}{l}\text { Stimulation of B cells } \\
\text { with S. aureus and flow } \\
\text { cytometry analysis }\end{array}$ & Human peripheral B cells & $\begin{array}{l}55 \% \text { reduction of IgM secretion by B cells and } 50 \% \text { reduction in ATP } \\
\text { secretion in environment of elevated glucose }\end{array}$ \\
\hline \multicolumn{6}{|c|}{ Eosinophils } \\
\hline 48 & 2013 & $\begin{array}{l}\text { Cross- } \\
\text { sectional } \\
\text { observational } \\
\text { study }\end{array}$ & $\begin{array}{l}\text { Quantification of } \\
\text { leukocytes }\end{array}$ & $\begin{array}{l}50 \text { patients with diabetic } \\
\text { ketoacidosis, } 50 \text { patients with } \\
\text { diabetic ketosis, } 50 \text { diabetic } \\
\text { patients with stable glycemic } \\
\text { control, } 50 \text { controls }\end{array}$ & $\begin{array}{l}\text { Non-DKA diabetics and normal controls have median normal eosinophil } \\
\text { counts of } 6595 / \mathrm{mm}^{3} \text { and } 6008 / \mathrm{mm}^{3} \text {, respectively, while DKA diabetics } \\
\text { median eosinophil count is } 28 / \mathrm{mm}^{3}\end{array}$ \\
\hline \multicolumn{6}{|c|}{ Fibroblasts } \\
\hline 41 & 2003 & $\begin{array}{l}\text { Parallel group } \\
\text { experimental } \\
\text { study }\end{array}$ & $\begin{array}{l}\text { Cell culture and } \\
\text { immunoassay of mice } \\
\text { fibroblasts }\end{array}$ & Diabetic mice & $\begin{array}{l}\text { Murine fibroblasts grown in vitro showed a } 75 \% \text { decrease in migration } \\
\text { compared to controls and were not stimulated by hypoxic conditions in } \\
\text { contrast to control fibroblasts which demonstrated a two-fold } \\
\text { upregulation in activity. Additionally, diabetic fibroblasts did not } \\
\text { increase VEGF production in response to hypoxic challenge while the } \\
\text { normal controls upregulation VEGF production three-fold }\end{array}$ \\
\hline 55 & 2007 & Review article & $\begin{array}{l}\text { Review of wound } \\
\text { healing in diabetes }\end{array}$ & $\begin{array}{l}\text { Diabetic foot ulcers using diabetic } \\
\text { mice }\end{array}$ & $\begin{array}{l}\text { Fibroblasts isolated from the non-healing edge of diabetic foot ulcers } \\
\text { show reduced migration and proliferation. }\end{array}$ \\
\hline 56 & 1999 & $\begin{array}{l}\text { Cross- } \\
\text { sectional } \\
\text { observational } \\
\text { study }\end{array}$ & $\begin{array}{l}\text { Evaluation of fibroblast } \\
\text { cultures using } \\
\text { microscopy }\end{array}$ & $\begin{array}{l}\text { Fibroblasts isolated from ulcers of } \\
4 \text { Type II diabetic patients }\end{array}$ & $\begin{array}{l}\text { Fibroblasts isolated from ulcers of Type II diabetics demonstrated } \\
\text { significantly reduced proliferation compared to controls and exhibited a } \\
\text { deranged morphology marked by multiple lamellar and vesicular } \\
\text { bodies, absence of microtubular structures, and a dilated endoplasmic } \\
\text { reticulum }\end{array}$ \\
\hline 57 & 1988 & $\begin{array}{l}\text { Parallel group } \\
\text { experimental } \\
\text { study }\end{array}$ & $\begin{array}{l}\text { Quantification of } \\
\text { cartilage and bone } \\
\text { collagen production }\end{array}$ & Diabetic rats & $\begin{array}{l}\text { Collagen production in articular cartilage and bone of diabetic mice was } \\
51 \% \text { and } 52 \% \text {, respectively, of collagen production in non-diabetic } \\
\text { controls. Non-collagen protein production in these tissues was not } \\
\text { found to be significantly reduced. }\end{array}$ \\
\hline \multicolumn{6}{|c|}{ Growth Factors } \\
\hline 40 & 2013 & $\begin{array}{l}\text { Parallel group } \\
\text { experimental } \\
\text { study }\end{array}$ & $\begin{array}{l}\text { Immunoassay of } \\
\text { proinflammatory } \\
\text { molecules }\end{array}$ & $\begin{array}{l}\text { Macrophages isolated from chronic } \\
\text { wounds of } 5 \text { type } 2 \text { diabetic } \\
\text { patients \& diabetic mice }\end{array}$ & $\begin{array}{l}\text { In Type } 2 \text { diabetic patients, the authors noted decreased levels of } \\
\text { healing-associated markers CD206, IGF-1, TGF-beta, and IL-10. } \\
\text { Furthermore, in diabetic mice, macrophage release of IGF-1 and TGF- } \\
\text { beta was maintained at significantly lower levels than control mice at } \\
\text { post injury day } 10\end{array}$ \\
\hline
\end{tabular}




\begin{tabular}{|c|c|c|c|c|c|}
\hline Ref \# & Year & Study Type & Objective & Population Investigated & Findings \\
\hline 41 & 2003 & $\begin{array}{l}\text { Parallel group } \\
\text { experimental } \\
\text { study }\end{array}$ & $\begin{array}{l}\text { Cell culture and } \\
\text { immunoassay of mice } \\
\text { fibroblasts }\end{array}$ & Diabetic mice & $\begin{array}{l}\text { Fibroblasts isolated from diabetic mice demonstrated a sevenfold } \\
\text { reduction in production of vascular endothelial growth factor compared } \\
\text { to controls }\end{array}$ \\
\hline \multicolumn{6}{|c|}{ Inflammatory Factors } \\
\hline 18 & 2010 & $\begin{array}{l}\text { Parallel group } \\
\text { experimental } \\
\text { study }\end{array}$ & $\begin{array}{l}\text { Microarray and flow } \\
\text { cytometry analysis }\end{array}$ & Mouse skin epithelium & $\begin{array}{l}\text { Elevated gene expression of TNF-alpha was observed in mouse skin } \\
\text { epithelium }\end{array}$ \\
\hline 36 & 2000 & $\begin{array}{l}\text { Parallel group } \\
\text { experimental } \\
\text { study }\end{array}$ & $\begin{array}{l}\text { Evaluation of wound } \\
\text { healing }\end{array}$ & Diabetic mice & $\begin{array}{l}\text { Diabetic mice showed elevated IL-1beta and TNF-alpha mRNA levels } \\
\text { into the late phase of repair, suggesting a prolonged inflammatory } \\
\text { response }\end{array}$ \\
\hline 40 & 2013 & $\begin{array}{l}\text { Parallel group } \\
\text { experimental } \\
\text { study }\end{array}$ & $\begin{array}{l}\text { Immunoassay of } \\
\text { proinflammatory } \\
\text { molecules }\end{array}$ & $\begin{array}{l}\text { Macrophages isolated from chronic } \\
\text { wounds of } 5 \text { type } 2 \text { diabetic } \\
\text { patients \& diabetic mice }\end{array}$ & $\begin{array}{l}\text { In Type } 2 \text { diabetic patients, the authors noted decreased levels of } \\
\text { healing-associated markers CD206, IGF-1, TFG-beta, and IL-10. } \\
\text { Furthermore, in diabetic mice, macrophage release of IGF-1 and TGF- } \\
\text { beta was maintained at significantly lower levels than control mice at } \\
\text { post injury day } 10\end{array}$ \\
\hline \multicolumn{6}{|c|}{ Monocytes } \\
\hline 34 & 1999 & Review article & $\begin{array}{l}\text { Review of immune } \\
\text { dysfunction in diabetic } \\
\text { patients }\end{array}$ & Humans with diabetes & $\begin{array}{l}\text { Decreased chemotaxis is seen in polymorphonuclear leukocytes of } \\
\text { patients with diabetes }\end{array}$ \\
\hline 35 & 2007 & Review article & $\begin{array}{l}\text { Review of the } \\
\text { pathogenesis and } \\
\text { management of } \\
\text { infections in diabetic } \\
\text { patients }\end{array}$ & Humans with diabetes & Reduced chemotaxis in diabetic patients when compared to controls \\
\hline 36 & 2000 & $\begin{array}{l}\text { Parallel group } \\
\text { experimental } \\
\text { study }\end{array}$ & $\begin{array}{l}\text { Evaluation of wound } \\
\text { healing }\end{array}$ & Diabetic mice & $\begin{array}{l}\text { Diabetic mice showed elevated IL-1beta and TNF-alpha mRNA levels } \\
\text { into the late phase of repair, suggesting a prolonged inflammatory } \\
\text { response }\end{array}$ \\
\hline \multicolumn{6}{|c|}{ Neutrophils } \\
\hline 34 & 1999 & Review article & $\begin{array}{l}\text { Review of immune } \\
\text { dysfunction in diabetic } \\
\text { patients }\end{array}$ & Humans with diabetes & $\begin{array}{l}\text { Monocytes of diabetic patients demonstrate decreased chemotaxis, } \\
\text { phagocytosis. Furthermore, monocytes of Type I diabetics have shown } \\
\text { lower production of IL-1 and IL- } 6 \text { after stimulation by LPS in } \\
\text { comparison to the monocytes of Type II diabetics and controls. }\end{array}$ \\
\hline 46 & 2003 & $\begin{array}{l}\text { Cross- } \\
\text { sectional } \\
\text { observational } \\
\text { study }\end{array}$ & $\begin{array}{l}\text { Measurement of serum } \\
\text { L-selectin using ELISA }\end{array}$ & 51 Type 2 diabetic patients & $\begin{array}{l}\text { Higher serum levels of L-selectin have been associated with the } \\
\text { increased leukocyte-endothelial cell adhesion }\end{array}$ \\
\hline \multicolumn{6}{|c|}{ NK Cells } \\
\hline 28 & 2013 & $\begin{array}{l}\text { Cross- } \\
\text { sectional } \\
\text { observational } \\
\text { study }\end{array}$ & $\begin{array}{l}\text { Analysis of NK cell } \\
\text { subsets }\end{array}$ & $\begin{array}{l}51 \text { Type II diabetic patients and } 54 \\
\text { age matched controls }\end{array}$ & $\begin{array}{l}\text { Decrease in NKG2D positive NK cells from } 55.5 \% \text { in controls to } 44 \% \text { in } \\
\text { diabetic patients and NKp } 46 \text { positive cells from } 50 \% \text { to } 23 \% \text {, resulting } \\
\text { in deducing degranulation capacity of the NK cells when challenged } \\
\text { with tumor cell lines }\end{array}$ \\
\hline
\end{tabular}




\begin{tabular}{|c|c|c|c|c|c|}
\hline Ref \# & Year & Study Type & Objective & Population Investigated & Findings \\
\hline 29 & 2007 & $\begin{array}{l}\text { Cross- } \\
\text { sectional } \\
\text { observational } \\
\text { study }\end{array}$ & $\begin{array}{l}\text { Analysis of peripheral } \\
\text { blood using flow } \\
\text { cytometry }\end{array}$ & 197 Type I diabetic patients & $\begin{array}{l}\text { Decrease in NKG2D receptor expression and decreased NKp30/p46 } \\
\text { expression } \\
\text { associated with reduced NK cell activation in diabetic patients }\end{array}$ \\
\hline 30 & 1994 & $\begin{array}{l}\text { Cross- } \\
\text { sectional } \\
\text { observational } \\
\text { study }\end{array}$ & $\begin{array}{l}\text { Immunofluorescence } \\
\text { analysis }\end{array}$ & $\begin{array}{l}25 \text { Type I diabetic patients and } 9 \\
\text { age-matched controls }\end{array}$ & $\begin{array}{l}\text { Lowered CD16+ NK cells numbers and cytotoxic activity in diabetic } \\
\text { patients }\end{array}$ \\
\hline \multicolumn{6}{|c|}{ Surface Adhesion Molecules } \\
\hline 46 & 2003 & $\begin{array}{l}\text { Cross- } \\
\text { sectional } \\
\text { observational } \\
\text { study }\end{array}$ & $\begin{array}{l}\text { Measurement of serum } \\
\text { sL-selectin using ELISA }\end{array}$ & 51 Type 2 diabetic patients & $\begin{array}{l}\text { SL-selectin levels were significantly elevated in Type } 2 \text { diabetic patients } \\
\text { when compared with controls. }\end{array}$ \\
\hline \multicolumn{6}{|c|}{ T Cells } \\
\hline 17 & 2012 & $\begin{array}{l}\text { Parallel group } \\
\text { experimental } \\
\text { study }\end{array}$ & Analysis of Tregs & STZ-induced diabetic mice & $\begin{array}{l}\text { Inducing diabetes in mice increases the number of circulating } \\
\text { CD4+CD25+ T regulatory cells but these cells showed defective } \\
\text { immunosuppressive function }\end{array}$ \\
\hline 18 & 2010 & $\begin{array}{l}\text { Parallel group } \\
\text { experimental } \\
\text { study }\end{array}$ & $\begin{array}{l}\text { Microarray and flow } \\
\text { cytometry analysis }\end{array}$ & Mouse skin epithelium & $\begin{array}{l}\text { Hyperglycemia reduces gamma delta T cell populations to half of that in } \\
\text { the normoglycemic state and those that remain are impaired in their } \\
\text { function by TNF-alpha }\end{array}$ \\
\hline 63 & 2002 & $\begin{array}{l}\text { Cross- } \\
\text { sectional } \\
\text { observational } \\
\text { study }\end{array}$ & $\begin{array}{l}\text { Analysis of T cells in } \\
\text { stable and unstable } \\
\text { angina }\end{array}$ & $\begin{array}{l}\text { Peripheral blood mononuclear cells } \\
\text { from patients with angina }\end{array}$ & CD4+CD28null T cells produce IFN-gamma \\
\hline
\end{tabular}

